\title{
Transgenic Mice Bearing a Human Mutant Thyroid Hormone $\beta 1$ Receptor Manifest Thyroid Function Anomalies, Weight Reduction, and Hyperactivity
}

\author{
Rosemary Wong,* Vyacheslav V. Vasilyev,* Yuan-Tsang Ting, ${ }^{\dagger}$ \\ David I. Kutler,* Mark C. Willingham, ${ }^{\neq}$Bruce D. Weintraub,* \\ and Sheue-yann Cheng ${ }^{\dagger}$ \\ * Molecular and Cellular Endocrinology Branch, National Institute of \\ Diabetes and Digestive and Kidney Diseases and ${ }^{\dagger}$ Laboratory of \\ Molecular Biology, National Cancer Institute, National Institutes of \\ Health, Bethesda, Maryland, U.S.A. \\ ${ }^{\ddagger}$ Department of Pathology \& Laboratory Medicine, Medical University \\ of South Carolina, Charleston, South Carolina, U.S.A.
}

\begin{abstract}
Background: Resistance to thyroid hormone (RTH) is a syndrome characterized by refractoriness of the pituitary and/or peripheral tissues to the action of thyroid hormone. Mutations in the thyroid hormone receptor $\beta$ (TR $\beta)$ gene result in TR $\beta 1$ mutants that mediate the clinical phenotype by interfering with transcription of thyroid hormone-regulated genes via a dominant negative effect. In this study, we developed transgenic mice harboring PV, a potent dominant negative human mutant TR $\beta 1$ devoid of thyroid hormone binding and transcriptional activation, as an animal model to understand the molecular basis of this human disease.

Materials and Methods: Standard molecular biology approaches were used to obtain a cDNA fragment containing mutant PV which was injected into the pronucleus of fertilized egg. Founders were identified by Southern analysis and the expression of PV in tissues was determined by RNA and immunohistochemistry. Thyroid function was determined by radioimmunoassays of
\end{abstract}

the hormones and the behavior of mice was observed using standard methods.

Results: The expression of mutant PV was directed by the $\beta$-actin promoter. Mutant PV mRNA was detected in all tissues of transgenic mice, but the levels varied with tissues and with different lines of founders. Thyroid function tests in transgenic mice with high expression of mutant PV showed a significantly ( $\sim 1.5$-fold $)$ higher mean serum total of L-thyroxine levels $(p<0.01)$ than those of nontransgenic mice. Moreover, thyroid-stimulating hormone levels were not significantly different from those of nontransgenic mice. In addition, these mice displayed decreased weights and a behavioral phenotype characterized by hyperactivity.

Conclusions: These mice have phenotypic features consistent with the commonly observed clinical features of RTH and could be used as a model system to better understand the action of mutant TR $\beta 1$ in a physiological context, which could lead to better treatment for this disease.

\section{INTRODUCTION}

Thyroid hormone receptors (TRs) are members of the nuclear receptor superfamily, which includes the vitamin $\mathrm{D}$ receptor, retinoic acid re-

Address correspondence and reprint requests to: Dr. Sheueyann Cheng, Building 37, Room 2D24, 37 Convent Drive 4255, Bethesda, MD 20892-4255, U.S.A. Tel: 301-496-

4280; Fax: 301-480-9676; e-mail: sycheng@helix.nih.gov. ceptor, retinoid $\mathrm{X}$ receptor (RXR) and steroid receptors. They act as nuclear transcription factors that bind to specific thyroid hormone response elements (TREs) on the promoters of 3,5,3'-triiodo-L-thyronine $\left(\mathrm{T}_{3}\right)$-responsive genes $(1,2)$. Two TR genes, $\alpha$ and $\beta$, located on chromosome 17 and 3, respectively, have been identified. Alternative splicing of the primary transcripts of these two genes yields three isoforms of $\mathrm{TR}, \alpha 1, \beta 1$, and $\beta 2$, each with a unique develop- 
mental and tissue-specific expression $(1,2)$. The transcriptional activity of TRs is not only regulated by $\mathrm{T}_{3}$ and the types of TREs, but also by other cellular proteins, including the tumor suppressor p53 (3), corepressors (4), coactivators (4), and other members of the nuclear receptor superfamily (1).

Resistance to thyroid hormone (RTH) is a genetic disease due to mutations in the TR $\beta$ gene $(5,6)$. This clinical syndrome was first described by Refetoff et al. (7) and is characterized by an inappropriately normal or elevated level of thyroid-stimulating hormone (TSH) for the elevated levels of circulating thyroid hormones. Clinical features include attention-deficit hyperactivity disorder (ADHD), decreased IQ, dyslexia, short stature, decreased weight, tachycardia, and cardiac disease $(5,6,8)$. TR $\beta$ mutants derived from RTH patients have reduced $\mathrm{T}_{3}$-binding affinities and transcriptional capacities and, unlike other nuclear receptor mutations causing hormone-resistance syndromes, act in a dominant negative fashion to cause the clinical phenotype $(5,6,9)$.

Until recently, all the studies of mutant TR $\beta$ action were performed in in vitro systems and in cell culture. The findings from these systems have well-recognized limitations when extrapolated to the physiological context. In one approach, Hayashi et al. (10) used an adenovirus to target mouse liver with a mutant TR $\beta 1$ to study the dominant negative action of the mutant receptor on this tissue. In terms of a whole animal model of RTH, it was initially postulated that the overexpression of v-erbA might produce a phenotype analogous to that seen in RTH (11). $V$ $\operatorname{erb} A$, which is the viral counterpart of the c-erbA gene that encodes the chicken TR $\alpha(12,13)$, is also a dominant negative transcription factor, but unlike TR, it is a potent oncogene. Transgenic (TG) mice overexpressing v-erbA under the control of the human $\beta$-actin promoter (11) had low thyroid hormone levels in the presence of inappropriately low TSH responses to Methimazole and thyroid follicle abnormalities, reduced fertility, decreases in body mass, abnormal mothering behavior, and hepatocellular carcinoma. Thus, these features were markedly different from those observed in RTH despite the close relationship between these two transcription factors. In a more recent study of TR $\beta$ knockout mice, Forrest et al. (14) found that these mice closely resembled the only kindred described with a recessive form of RTH (7) where the TR $\beta$ gene was deleted
(15) in that these mice had goiter, high L-thyroxine $\left(T_{4}\right)$ and $T_{3}$ values with inappropriately normal TSH levels, and deafness. However, unexpectedly and in marked contrast to the frequent presentation of behavioral abnormalities in kindreds with $\mathrm{RTH}$, these mice lacked any overt behavioral abnormalities. Thus, the mechanisms that mediate mutant TR $\beta$ action in the brain in dominantly inherited RTH are distinct to those in recessive RTH. Indeed, in this study in which we report the development of TG mice overexpressing a powerful dominant negative human mutant TR $\beta 1, P V$, under the control of the human $\beta$-actin promoter $(16,17)$, we observed behavioral abnormalities. PV was derived from a patient with severe RTH characterized by ADHD, short stature ( $<5$ percentile), low weight $(<5$ percentile), goiter, and tachycardia (18). PV has a unique mutation in exon 10 , a $\mathrm{C}$-insertion at codon 448 , which produces a frameshift of the carboxy terminal 16 amino acids of TR $\beta 1$, resulting in total loss of $\mathrm{T}_{3}$-binding and transcriptional activation (19). Thus, in contrast to v-erbA TG mice (11), TG mice harboring PV exhibited elevated thyroid hormone levels with inappropriately normal TSH levels, impaired weight gain, and hyperactivity, features which are similar to those seen in RTH. Moreover, PV TG mice differed from TR $\beta$ knockout mice in having a behavioral phenotype, which underscores the importance of these different animal models in the further understanding of the molecular basis of thyroid hormone action.

\section{MATERIALS AND METHODS}

\section{Plasmids}

Mutant PV TR $\beta 1$ cDNA constructed as previously described (19) was subcloned into the HindIII site of the human $\beta$-actin construct (BAP.2) (gift of S. Goff, Columbia University) and verified to be in the correct orientation by sequencing. The vector contains $3 \mathrm{~kb}$ of the $5^{\prime}$ flanking sequence from the human actin gene, exon 1 containing $5^{\prime}$ untranslated region from the same gene, $832 \mathrm{nt}$ of intervening sequence, $1.2 \mathrm{~kb}$ of the PV TR $\beta 1$ cDNA sequence, and a 500-nt fragment containing the SV40 polyadenylation signal. The injected DNA was a ClaI fragment containing 5.5 kb BAP.2-PV TR $\beta I$ cDNA with polyA site. 


\section{Generation and Analysis of Transgenic Founders and Offspring}

The injection of the purified ClaI fragment and preparation of TG mice were done according to the procedure of Hogan and Lacy (20). Founders were analyzed by HindIII restriction digestion of tail DNA to release the $1.4-\mathrm{kb}$ transgene, followed by Southern analysis using the $1.4-\mathrm{kb}$ HindIII PV-TR $\beta 1$ cDNA as a probe. Positive animals were mated and tail DNA from their offspring were analyzed as above. Animal studies were conducted in accordance with $\mathrm{NIH}$ guidelines for the care and use of laboratory animals.

\section{RNA Analysis}

Total RNA was prepared using a guanidiniumbased method according to the manufacturer's instructions (TRIzol ${ }^{\circ}$, Gibco-BRL, Gaithersburg, $M D)$. Tissue-specific expression of the transgene was determined using RNAse protection assay and reverse transcriptase-polymerase chain reaction (RT-PCR). The latter technique was used to determine the ratio of mutant PV to endogenous mouse levels of TR $\beta 1$ mRNA (PV:mTR $\beta 1$ ratio). For RNAse protection assay, a 410-bp riboprobe corresponding to nucleotides 895-1305 of the hTR $\beta 1$ cDNA was hybridized to $20 \mu \mathrm{g}$ total RNA to detect PV mRNA according to the manufacturer's protocol (RPA II, Ambion, Austin, TX). For RT-PCR, after treatment of RNA with RNAse-free DNAse I (Boehringer-Mannheim Biochemicals, Indianapolis, IN), $2 \mu \mathrm{g}$ of RNA was reverse transcribed using M-MLV RT (Clontech, Palo Alto, CA). Samples without M-MLV RT were also treated in an identical manner to be certain of specific reverse transcription. An aliquot $(10 \mu \mathrm{l})$ of the resultant $100 \mu \mathrm{l} \mathrm{cDNA}$ reaction was used for polymerase chain reaction (PCR). Primers to sequences common to human and mouse TR $\beta$ alleles were used to amplify a 378-bp fragment of both human (between 762 and 1140 nucleotides) and mouse (between 537 and 914 nucleotides) TR $\beta 1$ cDNAs, which, when digested with Pst 1 , yielded 2 fragments with the sizes of 134 and $244 \mathrm{bp}$ from human but not mouse TR $\beta$ l. The components of the PCR reaction per 50- $\mu$ l volume were: 30 pmoles each of forward and backward primer, $10 \mathrm{mM}$ dNTPs (Boehringer-Mannheim Biochemicals, Indianapolis, IN), $2 \mu \mathrm{Ci}\left[\alpha^{33} \mathrm{P}\right]$-dATP, $1 \times$ buffer $(100$ $\mathrm{mM}$ Tris- $\mathrm{HCl}, 15 \mathrm{mM} \mathrm{MgCl} 2,500 \mathrm{mM} \mathrm{KCl}$ ), and 1.25 units Taq (Boehringer-Mannheim Biochemicals, Indianapolis, IN). Cycling conditions were: $94^{\circ} \mathrm{C} 5^{\prime}$ for 1 cycle; $94^{\circ} \mathrm{C} 1^{\prime}, 55^{\circ} \mathrm{C}^{\prime}, 72^{\circ} \mathrm{C}$ $1^{\prime}$ for 30 cycles; and $94^{\circ} \mathrm{C} 1^{\prime}, 55^{\circ} \mathrm{C} 2^{\prime}, 72^{\circ} \mathrm{C} 15^{\prime}$ for 1 cycle. BAP-PV or mouse TR $\beta 1$ plasmid $(0.05 \mathrm{ng}$ ) was used for PCR to serve as controls for the position of expected bands on the gel and to ensure complete restriction enzyme digestion.

After purification of the PCR products using the SpinBind PCR purification system (FMC Bioproducts, Rockland, ME), restriction digestion with PstI was carried out and the different fragments separated on an $8 \%$ polyacrylamide gel. Ratios of PV:mTR $\beta 1$ mRNA were obtained using PhosphoImager analysis of the dried gel after overnight exposure (Molecular Dynamics, Sunnyvale, CA).

\section{Preparation of Specific PV Antibody and Detection of PV Protein in Liver by Immunohistochemistry}

Polyclonal anti-PV antibody $\mathrm{Tl}$ was prepared and affinity purified as described (21). Tl recognizes specifically the PV mutant but not the wild-type human TR $\beta 1$. For the detection of PV protein in liver and brain, frozen samples of liver and brain from nontransgenic (NTG) and TG mice of Family D were cryostat sectioned, fixed with acetone, and processed for immunohistochemistry as previously described (22) using monoclonal antiTR $\beta 1$ antibody C4 specific for the endogenous TR $\beta 1$ (21), Tl or a blank control omitting the first antibody step.

\section{Hormone Assays}

Whole blood was obtained by tail bleeding or cardiac puncture at the time of sacrifice. Total $\mathrm{T}_{4}$ and $T_{3}$ and free $T_{4}$ were measured using commercially available radioimmunoassays (RIA) for the rat hormones (GammaCoat $\mathrm{M}^{125} \mathrm{I}_{-} \mathrm{TT}_{4}$ RIA kit; GammaCoat ${ }^{125} \mathrm{I}_{-} \mathrm{TT}_{3}$ RIA kit; GammaCoat ${ }^{125} \mathrm{I}_{-} \mathrm{fT}_{4}$ [2-step] RIA kit, Incstar, Stillwater, MN). TSH assays were performed with an ${ }^{125} \mathrm{I}$-rat TSH RIA kit (Amersham, Arlington Heights, IL) as per protocol except that the TSH values were based on mouse TSH standards, reference preparation \#AFP 51718 MP (provided by A. F. Parlow, UCLA). All of these assays have previously been validated and used for the measurement of mouse thyroid function tests (11). Growth hormone assays were performed using an ${ }^{125} \mathrm{I}$-rat GH RIA kit (Amersham, Arlington Heights, IL) according to protocol. 
(A). Families A and G
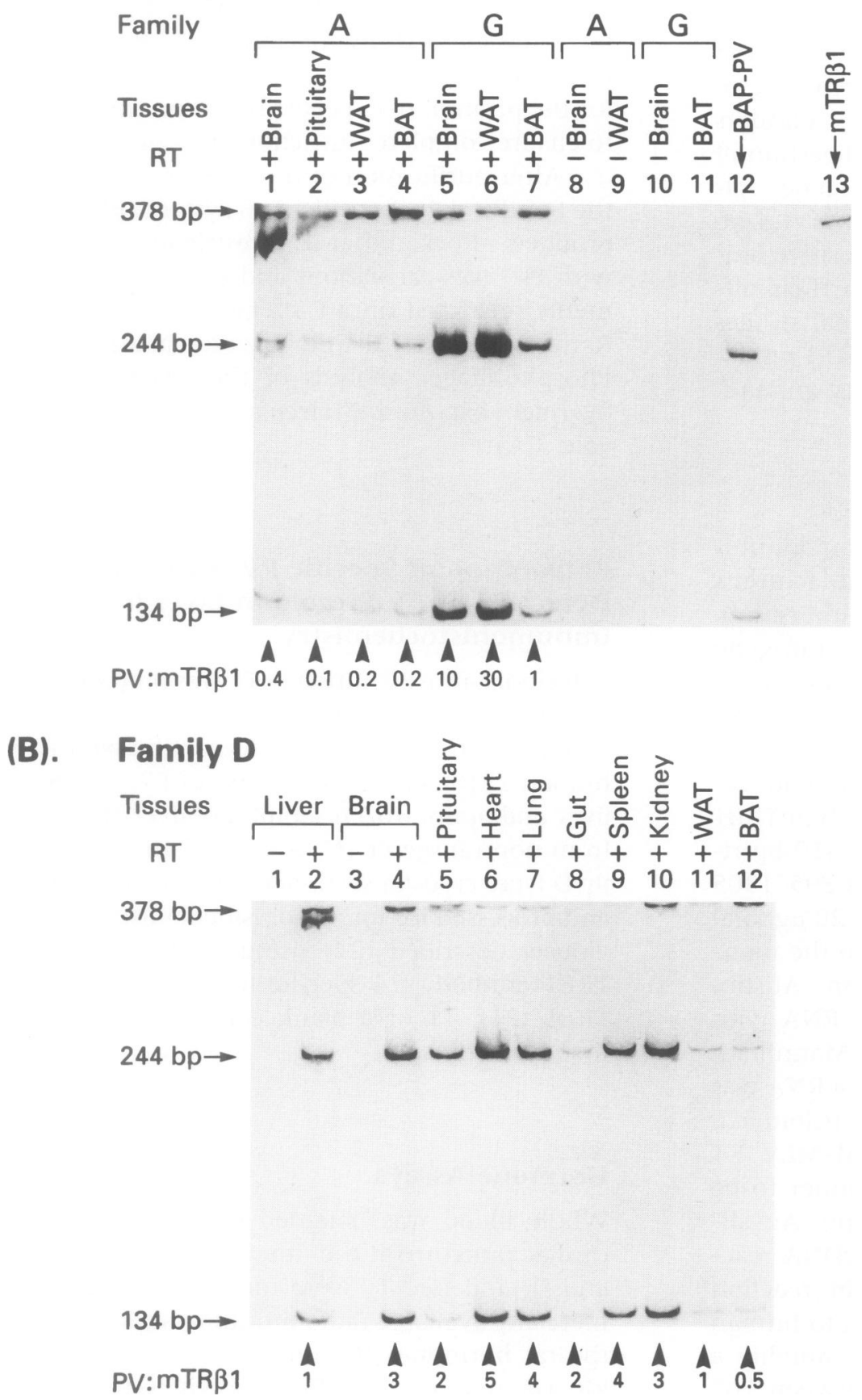

FIG. 1. Mutant to endogenous TRBI mRNA ratios

(A) Comparison of selected tissues from Fl Families $A$ and $G$ on the same gel, utilizing identical RT-PCR conditions to verify low and high expression, respectively. (B) A representative gel from a high-expressing mouse from Fl Family D. The relative amounts of endogenous TR $\beta 1$ mRNA among tissues agree with the findings of Oppenheimer et al. (34). After Pst 1 digestion of the PCR product, the $378 \mathrm{bp}$ represents the uncut fragment of amplified mouse endogenous TR $\beta 1$, and 244 bp and 134 bp derive from the cut human fragment of TR $\beta 1$. WAT, white adipose tissue; BAT, brown adipose tissue.

\section{Observation of Mice and Analysis of Their Behavior}

Weights were obtained every 1-2 weeks, beginning at weaning. The suckling and feeding behaviors of pups were also observed. Prior to drug treatment, measurements of activity levels were obtained before and after intraperitoneal (I.P.) administration of a saline placebo. Behavioral activity was assessed for 60 min between 1000 and $1600 \mathrm{hr}$ using a photocell activity cage monitor (Omnitech Electronics, Columbus, $\mathrm{OH}$ ) previously validated for studying locomotor activity in rodents (23). Nocturnal studies were also performed between 2000 and $0300 \mathrm{hr}$, as rodents are nocturnal animals and may display increases in activity at night. Computerized analyses of 

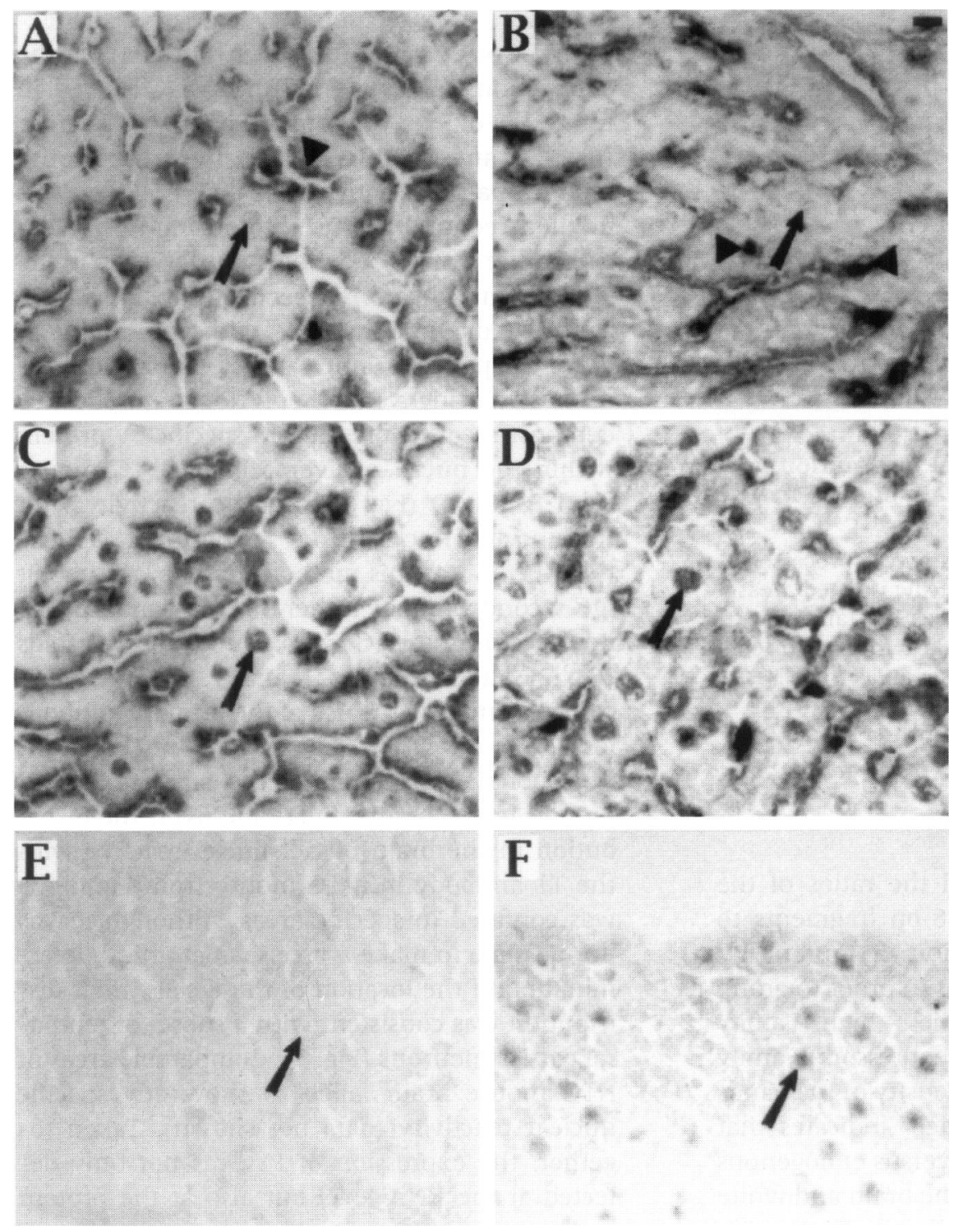

FIG. 2. Immunohistochemical localization of mutant PV protein in cells of liver

Liver from a NTG mouse (A, C, E) and a TG mouse from family $D(B, D, F)$ using mouse monoclonal antibody C4 (anti-wild type TR $\beta 1$ ) (C, D), rabbit polyclonal antibody Tl (anti-PV mutant $\operatorname{TR} \beta \mathrm{l})(\mathrm{E}, \mathrm{F})$ or a blank control deleting the first antibody step (A, B). The antimouse IgG conjugate (A-D) reacts with endogenous mouse IgG present in the sinusoidal spaces of the mouse liver (shown by arrowheads in A and B). Hepatocyte nuclei that contain TR are not easily detected in the blank control (A and B, arrows) because the levels of background labeling in the nuclei were low, allowing detection of specific TR localization as shown in $\mathrm{C}$ and $\mathrm{D}$ (arrows) by using anti-wildtype TR $\beta 1 \mathrm{C} 4$. When anti-PV antibody $\mathrm{Tl}$ is used, no specific nuclear labeling is detected in NTG hepatocytes (E, arrow), whereas hepatocyte nuclei from the TG mouse demonstrate easily detectable labeling $(\mathrm{F}$, arrow $).(\times 370$, bar $=10 \mu \mathrm{m})$. horizontal distance traveled, vertical movements, and stereotypy (repetitive actions e.g., grooming, head bobbing, recorded by the monitor as repeated breaks of the same set of laser beams) were obtained. Mice were then studied on low- and high-dose methylphenidate ( 2 and $10 \mu \mathrm{g} / \mathrm{kg}$, respectively) (Research Biochemicals Inc., Natick, MA), IP was administered $20 \mathrm{~min}$ following a saline placebo IP, and the mice were monitored for $60 \mathrm{~min}$.

\section{RESULTS}

\section{Establishment of Transgenic Mice and Analysis of Expression of Mutant PV}

Two separate microinjections of the PV transgene into fertilized eggs and subsequent implan- tation into foster mothers resulted in a total of 12 founders as determined by Southern analysis. Three founders (A, D, and G) were selected for breeding and their offspring was characterized. The PV transgene was transmitted to the Fl generation in a Mendelian fashion.

The expression of $\mathrm{PV}$ in the tissues of TG mice at the mRNA level was evaluated by RNase protection assay and RT-PCR. The latter was used to quantitatively assess the ratio of mutant $\mathrm{PV}$ to endogenous levels of mouse TR $\beta 1$ (mTR $\beta 1$ ). Using this assay, a 378-bp fragment was expected from endogenous $\mathrm{mTR} \beta 1$ as shown by the positive control (lane 13, Fig. 1A), whereas two fragments with sizes of $244 \mathrm{bp}$ and 134 bp were expected to be derived from mutant $\mathrm{PV}$ as indicated by the positive control (lane 12, 


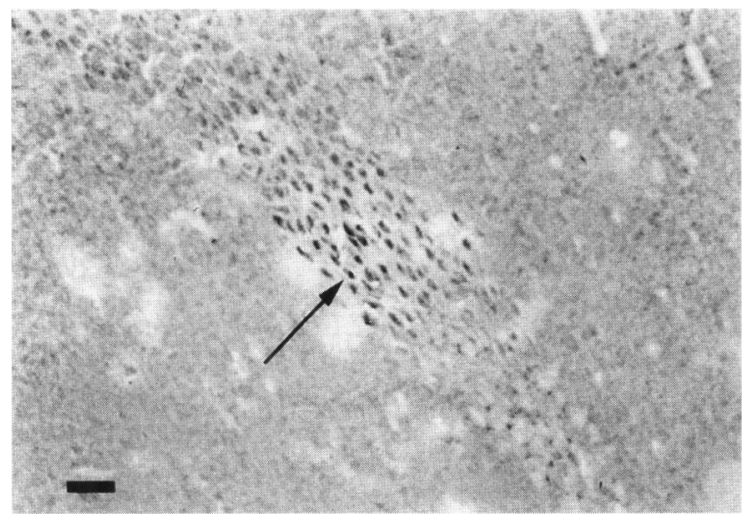

FIG. 3. Immunohistochemical localization using anti-PV antibody $T 1$ in brain of a TG mouse from F1 Family $D$

Frozen sections of TG mouse brain were processed as described for Fig. 2. Nuclei in specific isolated areas of the brain showed intense localization (arrow). These were consistent in their distribution with temporal cortical neurons. Comparable areas from NTG mouse brain did not show the same pattern with this antibody. $(\times 100$, bar $=50 \mu \mathrm{m})$.

Fig. 1A). Therefore, we used the ratios of the intensities of 244-bp and 378-bp fragments to indicate the relative expression of mutant PV versus the endogenous mTR $\beta 1$ in order to group mice into two general categories-high (Family G, lanes 5-7, Fig. 1A) or low expressors (Family A, lanes 1-4, Fig. 1A). The intensity of the bands as quantified by Phospholmager indicates that the ratios of expression of $P V$ versus endogenous mTR $\beta 1$ (PV:mTR $\beta 1$ ratio) in the brain and white and brown adipose tissues of Family $G$ were respectively higher than those of Family A (lanes 5 versus 1; lanes 6 versus 3; lanes 7 versus 4, Fig. 1A). Furthermore, in Family G, the extent of expression of PV varied from the PV:mTR $\beta 1$ ratio of 30 in white adipocyte tissue to the ratio of 1 in brown adipocyte tissue. Lanes 8-11, in which no bands were detected, were RT-PCR controls to ensure that the fragments detected in lanes 1-7 and 12-13 were not artifacts. Figure 1B shows the expression level of $\mathrm{PV}$ in tissues of another high-expressor mouse (Family D). Again, the extent of expression varied, ranging from the PV: mTR $\beta 1$ ratio of 1 in liver (lane 2, Fig. 1B) to 5 in heart (lane 5, Fig. 1B).

To detect the expression of PV protein, we developed a rabbit polyclonal antibody, $\mathrm{Tl}$, specifically against the unique frame-shifted C-terminal 16 amino acids of the mutant PV (21). Tl does not recognize the wild-type TR $\beta 1$ (21). We used immunohistochemistry to detect the expression of PV protein in liver. For control, the endogenous wild-type mTR $\beta 1$ was detected in the nuclei of liver cells of both NTG and TG mice (Fig. 2C and D, respectively) by using mouse monoclonal antibody C4 (21). While this method required the use of anti-mouse IgG labeling, the pattern of endogenous IgG seen in the hepatic sinusoids (arrowheads in Fig. 2A and B, controls) did not interfere with the ability to detect hepatocyte nuclear TR. Immunohistochemistry using a rabbit polyclonal antibody $\mathrm{Tl}$ demonstrated the presence of specific $\mathrm{PV}$ protein within the nuclei of liver cells of a TG mouse from Family D (Fig. 2F) and no reactivity with hepatocyte nuclei from a normal mouse (Fig. 2E). Since this method used an anti-rabbit IgG second antibody rather than anti-mouse IgG, no background $\operatorname{Ig} G$ was found in sinusoids (Fig. 2E and F). Figure 2A and B show the blank controls omitting the use of the primary antibodies.

We have also examined the expression of PV protein in the brain. Unlike the liver, the distribution in the brain of cell nuclei reactive with the Tl antibody in a TG mouse from Family D was confined to specific areas. Although it was not possible to make a precise anatomical determination of the location of these cells, their distribution was consistent with a subset of temporal cortical neurons (Fig. 3). Comparable areas of NTG mouse brain failed to show any specific nuclear reactivity (data not shown). Taken together, the expression of PV was not only detected at the RNA level but also at the protein level.

\section{Elevated Thyroid Hormone Levels and Inappropriate TSH Response in Transgenic Mice}

Thyroid function tests from TG founder mice showed significant elevations of both total $\mathrm{T}_{4}$ and free $\mathrm{T}_{4}$ levels (Fig. 4). The mean ( $\pm \mathrm{SEM}$ ) total $\mathrm{T}_{4}$ value for TG mice was $3.63 \pm 0.32 \mathrm{mg} / \mathrm{dl}$ and for NTG mice, $2.83 \pm 0.13 \mathrm{mg} / \mathrm{dl}(p<0.01)$. The free $\mathrm{T}_{4}$ value for $\mathrm{TG}$ mice was $2.14 \pm 0.12 \mathrm{ng} / \mathrm{dl}$ and $1.85 \pm 0.07 \mathrm{ng} / \mathrm{dl}$ for NTG mice $(t$-test, difference significant with $p<0.05$ ). However, there were no differences in total $\mathrm{T}_{3}$ values between TG $(1.14 \pm 0.02 \mathrm{ng} / \mathrm{ml})$ and NTG mice $(1.15 \pm 0.01 \mathrm{ng} / \mathrm{ml})$. Serum TSH was inappropriately normal for TG mice, with a mean of $47.7 \pm 3.71 \mathrm{ng} / \mathrm{dl}$, which was not significantly 

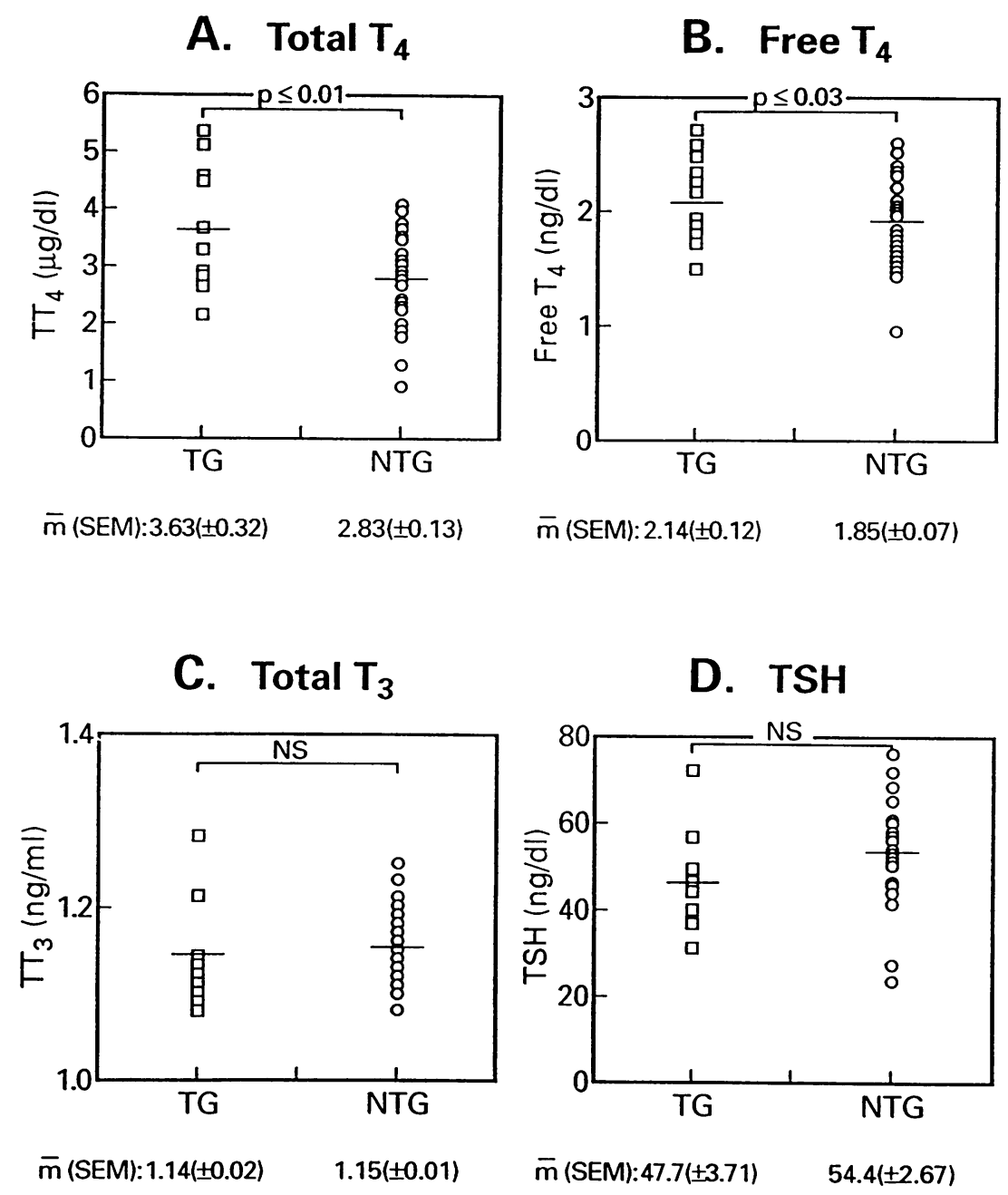

FIG. 4. Thyroid function tests of TG and NTG founder mice

These mice were shown to be positive for the transgene at the mRNA level by RNAse protection assay (see Material and Methods). (A) Total $T_{4}$. (B) Free $T_{4}$. (C) Total $T_{3}$. (D) TSH. The data are expressed as mean \pm standard error of the mean $(\overline{\mathrm{m}} \pm \mathrm{SEM} ; n=11$ for TG and $n=31$ for NTG). Statistical analysis was performed using Student's $t$ test. The differences are significant with confidence level of $p \leq 0.01$ for $\mathrm{A}$ and $p \leq 0.03$ for $\mathrm{B}$. The differences are nonsignificant (NS) for the TSH levels between TG and NTG with the confidence level of $p \geq 0.05$.

different from that of NTG mice $(p>0.05)$. Thyroid function tests were also conducted on the Fl members of Family D and similar results were found (data not shown). In contrast, TG mice of Fl Family A showed no differences in thyroid function tests compared with their negative littermates, which was consistent with a low PV: mTR $\beta 1$ ratio in the pituitary (lane 2, Fig. 1A). Taken together, these results are consistent with mild pituitary resistance.

\section{Impaired Weight Gain in Transgenic Mice}

In RTH kindreds, affected children have reduced weights, with the mean weight of affected children being $31.4 \pm 4.1 \mathrm{~kg}(n=57)$ compared with $55.2 \pm 5.7 \mathrm{~kg}(n=43)$ of their unaffected siblings $(p<0.001)(8)$. We therefore evaluated whether TG mice have the phenotype of impairment in weight gain similar to that observed for
RTH kindreds. Founder mice were used in the weight analyses that have also been shown to be positive for the transgene at the mRNA level by RNAse protection assay (data not shown). Figure 5A shows the comparison of weights between TG founder mice $(n=10)$ and their NTG littermates $(n=27)$ up to 21 weeks. TG mice weighed significantly less $(\sim 10-20 \%, p<0.05)$ than their negative littermates at each time point, indicating that $\mathrm{TG}$ mice have reduced weights similar to those seen for RTH kindreds. To see whether gender played a role in the difference seen in Fig. 5A, the data were reanalyzed based on gender. As shown in Fig. 5B, male TG mice showed a significantly greater reduction in weight at all time points and weighed about $22 \%$ less than NTG males at 21-27 weeks of age $(p<$ 0.008 ). In contrast, the weight difference between female TG and NTG mice was less prominent, with TG female mice weighing approxi- 


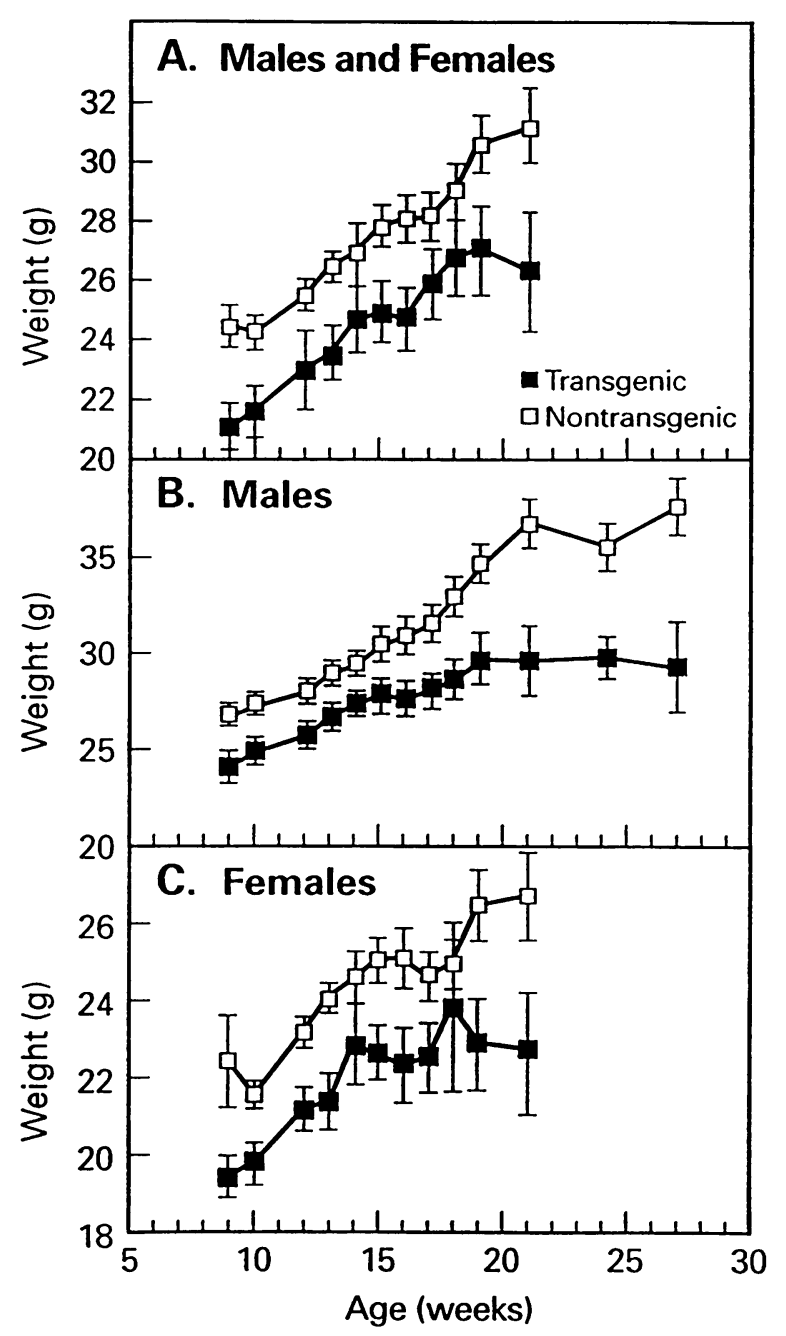

FIG. 5. Weight curves of TG and NTG founder mice

(A) As a group (TG, $n=10$; NTG, $n=27$ ). (B) Males (TG, $n=7$; NTG, $n=18$ ). (C) Females (TG, $n=3$; NTG, $n=9$ ). Weights are expressed as mean \pm SEM. Statistical analysis was performed using Student's $t$-test where $p<0.05$ was considered significant.

mately $9.5 \%$ less than their NTG littermates $(p<0.03)$ at all ages (Fig. 5C).

\section{Transgenic Mice Exhibit Hyperactivity}

The most common clinical feature of RTH requiring treatment is ADHD, which affects $73 \%$ of children and $42 \%$ of adults with RTH (8). This disorder is characterized by motor restlessness, impulsivity, and distractibility. Although ADHD is common in the general population (24), it is associated with only a small proportion of RTH cases; however, TR $\beta$ mutations represent the only known genetic association with ADHD (25). To assess whether TG mice exhibit the phenotype of increased activity consistent with that observed in RTH kindreds, we measured their nocturnal stereotypic activities (e.g., grooming, head bobbing, and licking). As shown in Fig. 6A, the activities of TG mice were increased by nearly 2 -fold, indicating that TG mice were more active than NTG mice.

However, there were no significant differences in the daytime activity levels between TG and NTG mice. These results could reflect the fact that mice are nocturnal animals and hence differences in activity could be expected to be accentuated at night. To demonstrate the increased daytime activity in TG mice, we took advantage of an observation seen in the treatment of ADHD in RTH kindreds. Current treatment modalities for ADHD patients are not optimal and consist mostly of methylphenidate, a dopamine reuptake blocker with a mechanism of action similar to that of amphetamine (26) and $\mathrm{T}_{3}$ empirically, in cases where ADHD occurs in the context of RTH. Whereas the normal pharmacological response to amphetamine and the dopamine reuptake blockers consists of generalized increases in various components of motor activity mediated mostly by dopaminergic transmission $(27,28)$, in ADHD there is a paradoxical reaction leading to amelioration of symptoms. According to these considerations, the increases in activity produced by methylphenidate in NTG mice should be attenuated in TG mice. Therefore, we challenged both TG and NTG mice with methylphenidate and compared their activities measured by two parameters: stereotypic counts (Fig. 6B) and the total distance traveled horizontally within $60 \mathrm{~min}$ (Fig. 6C). As shown in Fig. 6B, the increased stereotypic activity due to the administration of methylphenidate (compared with the basal activity from receiving saline only) was attenuated by approximately $40 \%$ in the TG mice from the high-expressor Family D. These observations are consistent with those seen in RTH kindreds. However, in Family A, in which the expression of the PV mutant was low, no significant attenuation was observed (Fig. 6B). The attenuation of the methylphenidate-induced increases in activity for Family D was further confirmed by the attenuation of about $50 \%$ in another activity parameter, total horizontal distance traveled (Fig. 6C). Similar degrees of attenuation of the methylphenidateinduced increases in activity were also observed 


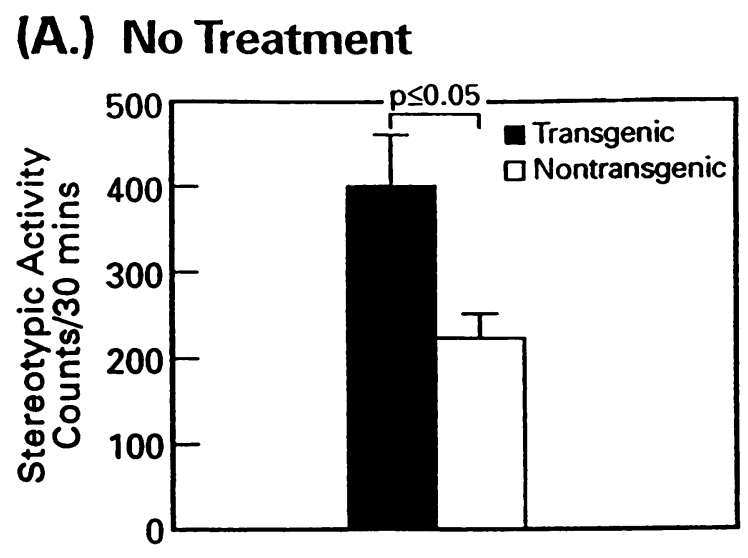

\section{(B.) Treatment}

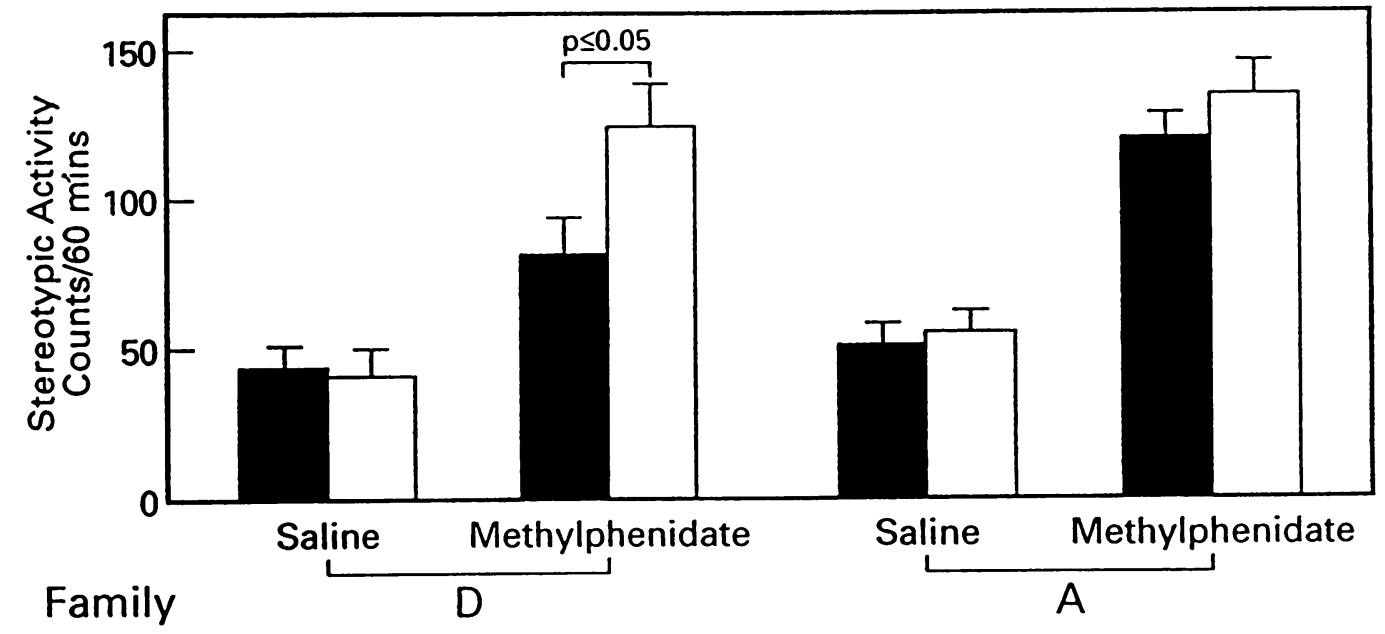

\section{(C.) Treatment}

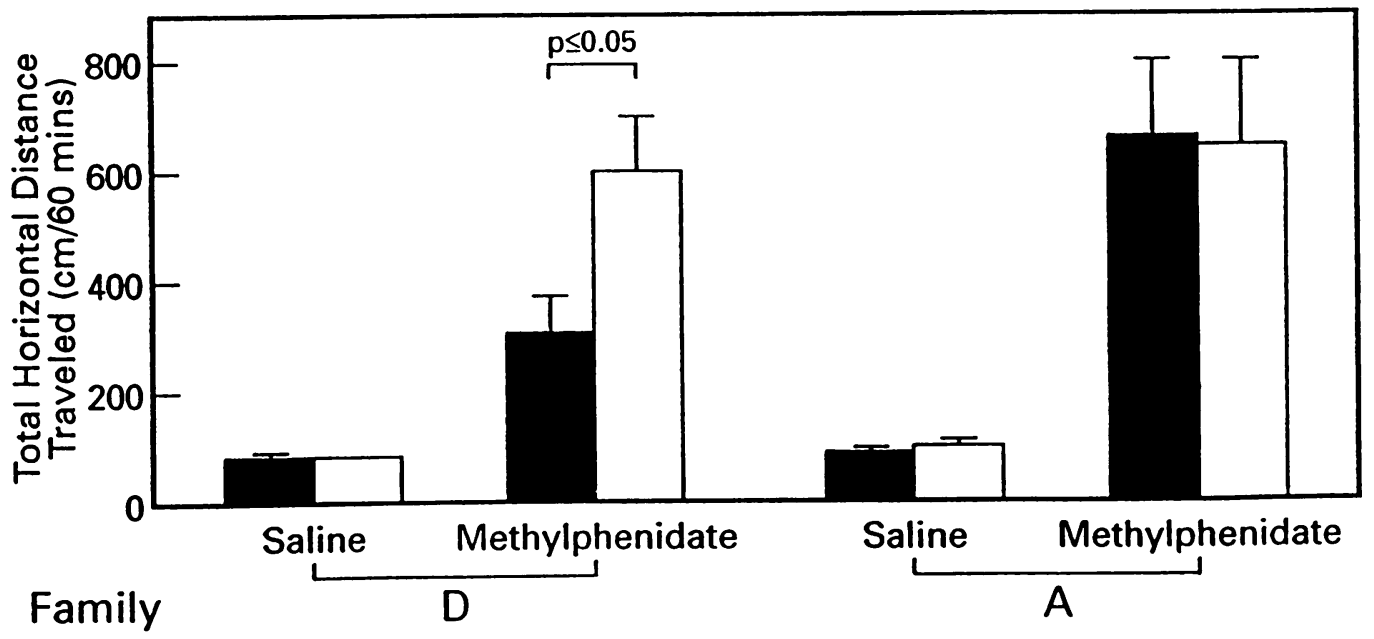

FIG. 6. Behavioral activity

(A) Nocturnal stereotypic activity counts over 30 min of hemizygous F2 mice of Family D (TG, $n=8$, NTG, $n=$ 11). (B) Daytime stereotypic activity counts over 60 min of Family D compared with Family A after I.P. injection of saline placebo and high-dose methylphenidate. (C) Daytime total horizontal distance traveled over 60 min of Family D compared with Family A after I.P. injection of saline placebo and high-dose methylphenidate. Values are given as mean \pm SEM and statistical analysis performed using ANOVA where $p<0.05$ was considered significant (StatView RII). 
in another high-expressor Family G (data not shown). Taken together, these results indicate that indeed, TG mice in which PV was abundantly expressed exhibited hyperactivity consistent with that seen in RTH kindreds.

\section{DISCUSSION}

In this study we have taken advantage of a naturally occurring, potent, dominant negative mutant PV to develop TG mice that have several phenotypes consistent with those in patients with the syndrome of RTH. First, consistent with the expression of mutant PV in the pituitary, the TG mice had increased levels of total and free $T_{4}$ and inappropriately normal TSH levels. Second, TG mice exhibited decreased weights and hyperactivity that are often present in patients with RTH.

From these TG mice, valuable information about mutant TR action previously unattainable by using cell culture and other in vitro techniques may now be obtainable. The first issue relates to how much expression of mutant versus normal TRs is required to produce a clinical phenotype. While the low-expressor Family A exhibited no hyperactivity, Families D and G showed similar degrees of hyperactivity despite greater levels of mutant PV in Family G. Taken together, these data also suggest that there may be a "threshold" level of mutant TR required, above which this phenotype becomes apparent. This "threshold" is currently unknown and may vary from tissue to tissue. Although not high in quantity, mutant protein was present in brain, as demonstrated by immunohistochemistry in which a specific anti-PV antibody was used, and its localization to cortical neurons may suggest a role in the behavioral phenotype observed. However, more extensive studies are needed before a clear correlation can be established.

Despite the significantly higher level of $\mathrm{T}_{4}$ in TG mice as compared to NTG mice, no differences in the $\mathrm{T}_{3}$ levels were seen between the two groups. This puzzling observation suggests that the level of expression of mutant PV is probably not the only factor that determines the phenotype. The "expected" responses could be modified by downstream regulation events. One of the possibilities is that the activation of type I deiodinase enzyme activity, which is responsible for the conversion of $T_{4}$ to $T_{3}$, is inhibited in a dominant negative fashion by mutant $\mathrm{PV}$, thus blocking the production of $T_{3}$.
The effect of mutant TR $\beta 1$ on weight and growth is complex and the underlying mechanisms are unknown. The impaired weight gain in these TG mice is similar to that found in patients with RTH. Although this effect is more pronounced in male TG mice, this male-predominant predilection for reduced weights was also present in v-erbA TG mice (11). Further study is required to determine whether this phenotype may be due to the effects of mutant TRs on the regulation of candidate genes known to have TREs, such as growth hormone and enzymes of the lipogenic pathway, e.g., malic enzyme and spot-14.

Another way in which this TG mouse model has been useful is in the evaluation of behavioral findings which, while not necessarily mimicking human ADHD, would lend support to the association of ADHD to TR $\beta$ gene mutations. Furthermore, the pattern of behavioral anomalies suggests the involvement of dopaminergic pathways. A central role of dopamine in hyperactivity has been demonstrated by several studies, including a report of dopamine Dl receptor knockout mice which showed basal hyperactivity and elimination of cocaine-induced hyperactivity (29), and a more recent study of a targeted mutation of the D3 dopamine receptor gene which resulted in hyperactivity (30). Similarly, in an earlier rat model of hyperactivity, neonatal intracisternal administration of 6-hydroxydopamine, which resulted in severe depletion of dopamine in the striatum and nucleus accumbens, also caused marked basal hyperactivity that was reversed by low doses of amphetamine or methylphenidate (31). Interestingly, it has been shown that dopamine may indirectly stimulate TRs to affect nuclear $\mathrm{T}_{3}$ responses via a ligand-independent fashion involving cross-talk with membrane-bound dopamine receptors and G-proteins (32). Furthermore, there is evidence from rodent studies suggesting that hypothyroidism may upregulate dopamine receptors (33). This may provide a possible explanation for the efficacy of dopamine reuptake blockers in improving the symptomatology of hyperactivity in RTH.

It is thus interesting to compare this model of dominant RTH with that of the recessive mouse model (14). Whereas the latter identified functions of TR $\beta$, such as for hearing and regulation of TSH in the pituitary, and TR $\beta$ cannot be substituted with TR $\alpha$ to carry these out, loss of TR $\beta$ in this mouse model apparently had only relatively mild or undetectable consequences for brain development. Indeed, our study confirms 
the importance of mutant TR $\beta$ function in disrupting certain neurological functions that result in the behavioral abnormalities observed in dominant RTH. The pathways that subserve the loss of receptor function and the presence of mutant receptor function may thus be different; our understanding of these mechanisms is enhanced by comparing different animal models.

\section{ACKNOWLEDGMENTS}

We thank Yetem Eshete for expert care of the mice and assistance with various mouse rodent procedures, Michael Smith, M.D. (Department of Pathology and Laboratory Medicine, Medical University of South Carolina), for advice in the interpretation of the neuronal distribution of reactive nuclei in sections of mouse brain, Philip Skolnick, Ph.D., for helpful discussions regarding the behavioral phenotype of our mice, William Wood, Ph.D., and Virginia Sarapura, M.D., for the mouse TR $\beta 1$ plasmid, Fredric Wondisford, M.D., Christoph Meier, M.D., Peter Hauser, M.D., and John Matochik, Ph.D., for helpful discussions, Mark Pineda for technical assistance and Mathis Grossmann, M.D., Simeon Taylor, M.D., and Francoise Davis, M.D., for critical review of the manuscript.

\section{REFERENCES}

1. Cheng S-y (1995) New insights into the structure and function of the thyroid hormone receptor. J. Biomed. Sci. 2: 77-89.

2. Oppenheimer JH, Schwartz HL, Strait KA (1994) Thyroid hormone action 1994: The plot thickens. Eur. J. Endocrinol. 130: 15-24.

3. Yap N, Yu C-L, Cheng S-y (1996) Modulation of the transcriptional activity of thyroid hormone receptors by the tumor suppressor p53. Proc. Natl. Acad. Sci. U.S.A. 93: 42734277.

4. Horwitz KB, Jackson TA, Bain DL, Richer JK, Takimoto GS, Tung L (1996) Nuclear receptor coactivators and corepressors. Mol. Endocrinol. 10: 1 167-1177.

5. Refetoff S, Weiss RE, Usala SJ (1993) The syndromes of resistance to thyroid hormone. Endocr. Rev. 14: 348-399.

6. Usala SJ (1995) New developments in clinical and genetic aspects of thyroid hormone resistance syndromes. The Endocrinologist 5: 68-76.
7. Refetoff S, DeWind LT, DeGroot LJ (1967) Familial syndrome combining deaf mutism, stippled epiphyses, goiter, and abnormally high PBI: Possible target organ refractoriness to thyroid hormone. J. Clin. Endocrinol. Metab. 27: 279-294.

8. Brucker-Davis F, Skarulis MC, Grace MB, Benichou J, Hauser P, Wiggs E, Weintraub BD (1995) Genetic and clinical features of 42 kindreds with resistance to thyroid hormone: The NIH prospective study. Ann. Intern. Med. 123: 572-583.

9. Yen PM, Chin WW (1994) Molecular mechanisms of dominant negative activity by nuclear hormone receptors. Mol. Endocrinol. 8: 1450-1454.

10. Hayashi Y, Mangoura D, Refetoff S (1996) A mouse model of resistance to thyroid hormone produced by somatic gene transfer of a mutant thyroid hormone receptor. Mol. Endocrinol. 10: 100-106.

11. Barlow C, Meister B, Lardelli M, Lendahl U, Vennstrom B (1994) Thyroid abnormalities and hepatocellular carcinoma in mice transgenic for v-erbA. EMBO J. 13: 4241-4250.

12. Sap J, Munoz A, Damm K, Goldberg Y, Ghysdael J, Leutz A, Beug H, Vennstrom B (1986) The c-erbA protein is a high affinity receptor for thyroid hormone. Nature 324: 635-640.

13. Weinberger C, Thompson CC, Ong ES, Lebo R, Gruol DJ, Evans RM (1986) The c-erbA gene encodes a thyroid hormone receptor. Nature 324: 641-646.

14. Forrest D, Hanebuth E, Smeyne RJ, Everds N, Stewart CL, Wehner JM, Curran T (1996) Recessive inheritance to thyroid hormone in mice lacking thyroid hormone receptor $\beta$ : Evidence for tissue-specific modulation of receptor function. EMBO J. 15: 3006-3015.

15. Takeda K, Sakurai A, DeGroot LJ, Refetoff S (1992) Recessive inheritance of thyroid hormone resistance caused by complete deletion of the protein-coding region of the thyroid hormone receptor- $\beta$ gene. J. Clin. Endocrinol. Metab. 74: 49-55.

16. Ray P, Higgins KM, Tan JC, Chu TY, Yee NS, Nguyen H, Lacy E, Besmer P (1991) Ectopic expression of a $c-k i t^{\mathrm{W} 42}$ minigene in transgenic mice: Recapitulation of $\mathrm{W}$ phenotypes and evidence for c-kit function in melanoblast progenitors. Genes Dev. 5: 2265-2273.

17. Gunning P, Leavitt J, Muscat G, Ng S-Y, Kedes L (1987) A human beta-actin expression vector system directs high-level accu- 
mulation of antisense transcripts. Proc. Natl. Acad. Sci. U.S.A. 84: 4831-4835.

18. Parrilla RA, Mixson AJ, McPherson JA, McClaskey JH, Weintraub BD (1991) Characterization of seven novel mutations of the c-erbA $\beta$ gene in unrelated kindreds with generalized thyroid hormone resistance. Evidence for two "hot spot" regions of the ligand binding domain. J. Clin. Invest. 88: 2123-2130.

19. Meier CA, Dickstein BM, Ashizawa K, McClaskey JH, Muchmore P, Ransom SC, Menke JB, Hao E-H, Usala SJ, Bercu BB, Cheng S-y, Weintraub BD (1992) Variable transcriptional activity and ligand binding of mutant beta-1 3,5,3'-triiodothyronine receptors from four families with generalized resistance to thyroid hormone. Mol. Endocrinol. 6: 248-258.

20. Hogan B, Lacy E (1986) Manipulating the Mouse Embryo. Cold Spring Harbor Laboratory Press, Cold Spring Harbor, New York.

21. Bhat MK, McPhie P, Ting Y-T, Zhu X-G, Cheng S-y (1995) Structure of the carboxyterminal region of thyroid hormone nuclear receptor and its possible role in hormonedependent intermolecular interactions. Biochemistry 34: 10591-10599.

22. Hasumura S, Kitagawa S, Lovelace E, Willingham MC, Pastan I, Cheng S-y (1986) Characterization of a membrane-associated 3,3',5-triiodo-L-thyronine binding protein by use of monoclonal antibodies. Biochemistry 25: 7881-7888.

23. Fitzgerald RE, Berres M, Schaeppi U (1988) Validation of a photobeam system for assessment of motor activity in rats. Toxicology 49: 433-439.

24. Zametkin AJ, Rapoport JL (1987) Neurobiology of attention-deficit disorder with hyperactivity: Where have we come in 50 years? J. Am. Acad. Child. Adolesc. Psychiatry 26: 676-686 [Erratum, (1988) 27: 338].

25. Hauser P, Zametkin AJ, Martinez B, Vitiello B, Matochik JA, Mixson AJ, Weintraub BD (1993) Attention deficit-hyperactivity disorder in people with generalized resistance to thyroid hormone. N. Engl. J. Med. 328: 9971001.
26. Shenker A (1992) The mechanism of action of drugs used to treat attention-deficit hyperactivity disorder: Focus on catecholamine receptor pharmacology. Adv. Pediatr. 39: 337382.

27. Malone MA, Kershner JR, Swanson JM (1994) Hemispheric processing and methylphenidate effects in attention-deficit hyperactivity disorder. J. Child Neurol. 9: 181-189.

28. Shaywitz BA, Teicher MH, Cohen DJ, Anderson GM, Young JG, Levitt P (1984) Dopaminergic but not adrenergic mediation of hyperactivity and performance deficits in the developing rat pup. Psychopharmacology 82: 73-77.

29. $\mathrm{Xu} \mathrm{M}, \mathrm{Hu} \mathrm{X}-\mathrm{T}$, Cooper $\mathrm{DC}$, Moratalla $\mathrm{R}$, Graybiel AM, White FJ, Tonegawa S (1994) Elimination of cocaine-induced hyperactivity and dopamine-mediated neurophysiological effects in dopamine D1 receptor mutant mice. Cell 79: 945-955.

30. Accili D, Fishburn CS, Drago J, Steiner H, Lachowicz JE, Park B-H, Gauda EB, Lee EJ, Cool MH, Sibley DR, Gerfen CR, Westphal H, Fuchs $S$ (1996) A targeted mutation of the D3 dopamine receptor gene is associated with hyperactivity in mice. Proc. Natl. Acad. Sci. U.S.A. 93: 1945-1949.

31. Archer T, Danysz W, Fredriksson A, Jonsson G, Luthman J, Sundstrom E, Teiling A (1988) Neonatal 6-hydroxydopamine-induced dopamine depletions: Motor activity and performance in maze learning. Pharmacol. Biochem. Behav. 31: 357-364.

32. Power RF, Mani SK, Codina J, Conneely OM, O'Malley BW (1991) Dopaminergic and ligand-independent activation of steroid hormone receptors. Science 254: 1636-1639.

33. Crocker AD, Overstreet DH (1984) Modification of the behavioral effects of haloperidol and of dopamine receptor regulation by altered thyroid status. Psychopharmacology 82: 102-106.

34. Strait KA, Schwartz HL, Perez-Castillo A, Oppenheimer JH (1990) Relationship of cerbA mRNA content to tissue triiodothyronine nuclear binding capacity and function in developing and adult rats. J. Biol. Chem. 265: 10514-10521. 